\title{
OBSERVATIONS ON THE EFFECT OF MAGNESIUM ON BLOOD COAGULATION
}

\author{
BY \\ R. G. HUNTSMAN, B. A. L. HURN, AND H. LEHMANN \\ From Lewisham Group Laboratory, Lewisham Hospital, and the Department of Pathology, \\ St. Bartholomew's Hospital, London
}

(RECEIVED FOR PUBLICATION OCTOBER 27, 1959)

Previous observations on the effect of oral magnesium and peptone on thrombin generation time are examined. The smallest amounts of magnesium and peptone regularly producing a significant shift demonstrable after one hour are $0.25 \mathrm{~g}$. magnesium and $15 \mathrm{~g}$. peptone.

The oral effect can be reproduced by the intravenous injection of magnesium. The minimum amount required is $50 \mathrm{mg}$. The effect is transient, and after 30 minutes can no longer be demonstrated.

Amounts of magnesium of the same order as those acting on intravenous injection can produce a shift of thrombin generation time in vitro. This action of magnesium in vitro can be antagonized by the addition of calcium.

Small amounts of magnesium added to fresh unclotted human plasma prolong the clotting time considerably. This action was shown to be due to an antagonism between $\mathrm{Mg}^{++}$and $\mathrm{Ca}^{++}$, both competing for combination with clotting factors (Greville and Lehmann, 1944). Such ion antagonism had been demonstrated in muscle and in nerve end-plates where the breakdown of adenosine triphosphate is activated by $\mathrm{Ca}^{+}+$in muscle and by $\mathrm{Mg}^{++}$in end-plates (Greville and Lehmann, 1943). The amount of magnesium required to demonstrate this effect in vitro was about 10 times the normal plasma level, and considerably greater than could be practically achieved in vivo. Attempts to test the action of magnesium in vivo were, however, made, notably in Germany, where, during and shortly after the 1939-45 war, magnesium sulphate was widely used as a muscle relaxant. It was noted that the blood of some patients examined post mortem after such treatment had remained unclotted. Schnitzler (1957) has summarized these experiences in his report on the use of $200 \mathrm{mg}$. of magnesium given three times daily, post partum, to prevent thrombosis. We have not been able to confirm his results, which indicated a highly significant prolongation of the whole blood clotting-time after a single dose of $300 \mathrm{mg}$. of magnesium. Malkiel-Shapiro, Bersohn, and Terner (1956) claimed that they improved the clinical state of patients with coronary disease when they administered magnesium parenterally. This they related to an effect of the magnesium on the coagulation mechanism. Brown, McGandy, Gillie, and Doyle (1958) were unable to find such a relation between magnesium and lipids in health or in disease. Anstall, Huntsman, Lehmann, Hayward, and Weitzman (1959) described the effect of the oral administration of $1 \mathrm{~g}$. magnesium on the clotting processes. Peptone had to be given with the magnesium to increase its absorption. This was thought to be due to the effect of amino-acids on the solubility of sparingly soluble salts of divalent cations, as demonstrated by Lehmann and Pollak (1942). Glutamic acid was also effective. To demonstrate the effect it was necessary to use the whole blood thrombin generation test (Macfarlane and Biggs, 1953), rather than the clotting time (Lee and White). A delay in thrombin generation of at least four minutes was obtained in successful experiments one hour after the administration of $1 \mathrm{~g}$. $\mathrm{Mg}^{++}$ and $50 \mathrm{~g}$. peptone. Both had to be given together, and neither could produce this effect alone. It was not always possible to demonstrate a rise in the serum magnesium concentration in otherwise successful tests.

The present paper describes attempts to elucidate the following aspects of this effect:

(1) The minimum amount of orally administered magnesium and peptone required to produce a shift in thrombin generation time ; 
(2) the relation between the effect obtained by orally administered magnesium and that obtained by intravenous injection;

(3) the relation between the effect obtained by intravenous injection and that exerted by the addition of magnesium to fresh blood in vitro.

\section{Experimental Procedure}

Macfarlane and Biggs's thrombin generation test (1953) was performed as previously described (Anstall et al., 1959). For the work in vitro, $5 \mathrm{ml}$. of blood was drawn into a siliconed syringe already containing either $0.1 \mathrm{ml}$. of water or the salts under investigation dissolved in a constant volume of $0.1 \mathrm{ml}$. of water.

\section{Results}

Varying the Quantity of Oral Magnesium and Peptone.-The same effect obtained with $1 \mathrm{~g}$. of magnesium and $50 \mathrm{~g}$. of peptone could also be produced with $0.25 \mathrm{~g}$. of magnesium and $15 \mathrm{~g}$. of peptone, but, whereas with the first amounts the shift in thrombin generation could be demonstrated for five to six hours, with the second amounts it was present after one hour, but could no longer be found after two hours. Lowering the magnesium dose below $0.25 \mathrm{~g}$. yielded equivocal results, regardless of how much peptone was given; and lowering the peptone below $15 \mathrm{~g}$. yielded, with some individual constancy, negative results in some, and equivocal or positive results in other subjects. Table I shows results of a typical series of experiments performed on one individual at intervals of four to seven days.

TABLE I

EFFECT OF ORAL MAGNESIUM AND PEPTONE ON THROMBIN GENERATION TIME

\begin{tabular}{|c|c|c|c|c|}
\hline \multicolumn{2}{|c|}{ Oral Dose (g.) } & \multicolumn{3}{|c|}{ Thrombin Generation Time (min.) } \\
\hline $\begin{array}{l}\text { Magnesium } \\
\text { Citrate } \\
\text { (g. Mg) }\end{array}$ & $\begin{array}{l}\text { Peptone } \\
\text { (g.) }\end{array}$ & $\begin{array}{l}\text { Before } \\
\text { Dose }\end{array}$ & $\begin{array}{c}\text { One } \\
\text { Hour after } \\
\text { Dose }\end{array}$ & Shift \\
\hline $\begin{array}{l}0.5 \\
0.5 \\
0.25 \\
0.25 \\
0.25\end{array}$ & $\begin{array}{c}50 \\
30 \\
30 \\
15 \\
7 \cdot 5\end{array}$ & $\begin{array}{l}10 \\
12 \\
13 \frac{1}{2} \\
12 \frac{1}{2} \\
13\end{array}$ & $\begin{array}{l}15 \frac{1}{2} \\
18 \\
17 \frac{1}{2} \\
18 \\
15\end{array}$ & $\begin{array}{l}5 \frac{1}{2} \\
6 \\
4 \\
5 \frac{1}{2} \\
2\end{array}$ \\
\hline
\end{tabular}

Injection of Magnesium.-Blood was withdrawn first to determine the basal time of thrombin generation. Afterwards, magnesium sulphate or magnesium chloride was injected intravenously in a volume of 1 to $2 \mathrm{ml}$. Blood was withdrawn five minutes later to allow for a thorough distribution of the magnesium. A shift in thrombin generation of four to five minutes' duration was found regularly after the injection of $50 \mathrm{mg}$. $\mathrm{Mg}^{++}$. Some effect could be found 15 minutes

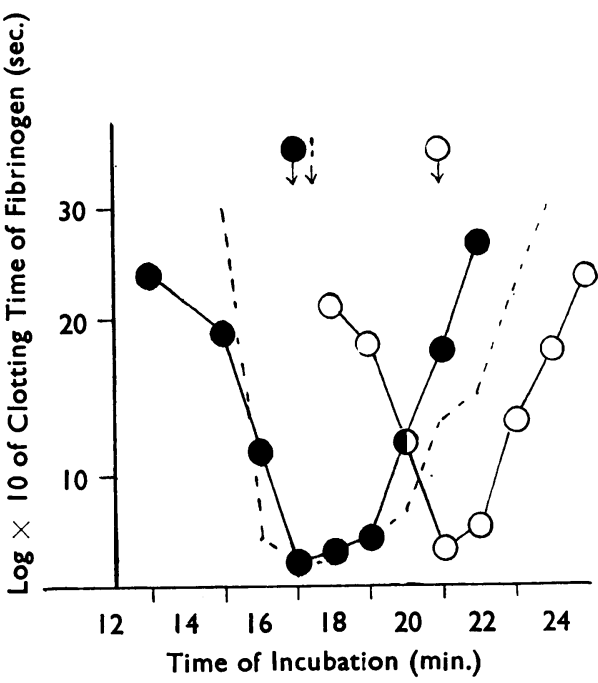

FIG. 1. Whole blood thrombin generation before, $5 \mathrm{~min}$. after, and $30 \mathrm{~min}$. after intravenous injection of $50 \mathrm{mg}$. of magnesium ion. Peak of thrombin generation before injection $17 \mathrm{~min}$., $5 \mathrm{~min}$. after injection $21 \mathrm{~min}$., and $30 \mathrm{~min}$. after injection $17 \frac{1}{2} \mathrm{~min}$. Before, $\mathrm{O}$ - -05 minutes after, and $\ldots-\ldots$ minutes after injection of $50 \mathrm{mg}$. $\mathrm{Mg}^{++}$.

after the injection of $50 \mathrm{mg}$., but it had vanished after 30 minutes. No significant shift was obtained after the injection of $25 \mathrm{mg}$. of the ion.

The transient nature of the change after the intravenous injection is in marked contrast to the action of the orally administered magnesium and peptone (1 g. and $50 \mathrm{~g}$. respectively), lasting for six hours. It is evident that, once absorbed, the effect of magnesium on clotting is rapidly neutralized, and it would, therefore, appear that the slow absorption after taking magnesium by mouth may be therapeutically advantageous. Judging from the rapidity with which the effect of intravenously administered magnesium diminishes, it might be assumed that even after only five minutes a decay in activity may already have occurred. Thus, it is possible that were this decay not so pronounced (or, as in oral dosage, if the magnesium slowly and continuously enters the blood stream), a much smaller quantity might have a significant effect. This could account for the frequent failure to demonstrate a rise in serum magnesium in otherwise successful experiments.

Experiments in Vitro.-Table II shows two typical experiments demonstrating the effect of small amounts of magnesium added to freshdrawn blood. The amount of magnesium added in vitro was of the same order as those which 
TABLE II

EFFECT IN VITRO OF MAGNESIUM ${ }^{++}$ON THROMBIN GENERATION DEMONSTRATION OF $\mathrm{MG}^{++} \mathrm{CA}^{++}$ANTAGONISM

\begin{tabular}{|c|c|c|c|c|}
\hline \multirow{2}{*}{$\begin{array}{l}\text { Experi- } \\
\text { ment }\end{array}$} & \multirow{2}{*}{$\underset{\left(\mathbf{m g} \cdot \mathbf{M g}^{+++}\right)}{\mathbf{M g C l}}$} & \multirow{2}{*}{$\underset{\left(\mathrm{mg} \cdot \mathrm{Ca}^{++}\right)}{\mathrm{CaCl}_{2}}$} & \multicolumn{2}{|c|}{$\begin{array}{c}\text { Thrombin Generation } \\
\text { Time (min.) }\end{array}$} \\
\hline & & & Peak & Shift \\
\hline I & $\begin{array}{l}0 \cdot 15 \\
0 \cdot 15 \\
0 \cdot 15 \\
0 \cdot 15\end{array}$ & $\begin{array}{l}1.5 \\
0.5 \\
0.5 \\
0 \cdot 1\end{array}$ & $\begin{array}{l}16 \\
24 \\
16 \frac{1}{2} \\
25 \\
18 \\
19 \\
17 \\
24 \frac{1}{2}\end{array}$ & $\begin{array}{l}8 \\
9^{\frac{1}{2}} \\
2 \\
3 \\
1 \\
8 \frac{1}{2}\end{array}$ \\
\hline II & $\begin{array}{l}0.3 \\
0.3\end{array}$ & $\begin{array}{l}0.5 \\
0.5\end{array}$ & $\begin{array}{l}23 \\
37 \frac{1}{2} \\
21 \\
26 \\
24 \frac{1}{2}\end{array}$ & $\begin{array}{c}14 \frac{1}{2} \\
-2 \\
3 \\
1 \frac{1}{2}\end{array}$ \\
\hline
\end{tabular}

Blood samples were taken at half-hourly intervals from two individuals. Each $5 \mathrm{ml}$. of blood was added in the syringe to $0.1 \mathrm{ml}$. of water or salt solution.

had produced a shift in thrombin generation in vivo. Equivalent amounts of potassium chloride and potassium sulphate had no effect. The fact that magnesium at such concentrations caused a shift in thrombin generation in vitro suggests that the action in vivo is directly on the blood, rather than intermediately on some other organ or system in the body.

Table II also illustrates another aspect of the magnesium effect. We had previously suggested (Anstall et al., 1959) that $\mathrm{Mg}^{++}$acted by competing with $\mathrm{Ca}^{++}$when it was added to a clotting system in which $\mathrm{Ca}^{++}$was in its optimal concentration. Large amounts of $\mathrm{Ca}^{+}+$added to blood are, of course, known to inhibit clotting. Furthermore, $\mathrm{Mg}^{++}$will antagonize $\mathrm{Ca}^{++}$when this ion is at its optimal concentration. If $\mathrm{Ca}^{++}$ is below its optimal concentration, $\mathrm{Mg}^{++}$may actually activate the process which is catalysed by $\mathrm{Ca}^{++}$, since on taking its place in that process it will not replace available $\mathrm{Ca}^{++}$but complement the insufficient amount of catalyst available. These relationships have been set out in detail by Greville and Lehmann (1943, 1944), whose work took its origin from the contradictory results reported on the effect of $\mathrm{Mg}^{++}$on the adenosine triphosphate splitting activity of myosin, some workers having described an activation, others an inhibition. Since then Born (1956) has reported that platelets have a high adenosine triphosphate content which falls rapidly on clotting, and Bettex-Galland and Lüscher (1959) have described an actomyosin-like protein prepared from platelets.

It was found that $0.5 \mathrm{mg}$. of $\mathrm{Ca}^{++}$added to $5 \mathrm{ml}$. of blood had no significant effect on thrombin generation. This quantity was, therefore, considered suitable for demonstrating any possible antagonism of $\mathrm{Ca}^{++}$on the effect of $\mathrm{Mg}^{++}$(see Table II). It will be seen in Table II that $0.5 \mathrm{mg}$. of $\mathrm{Ca}^{++}$by itself did not influence the thrombin generation time but that it considerably shortened the shift produced by $0.15 \mathrm{mg}$. or $0.3 \mathrm{mg}$. of $\mathrm{Mg}^{++}$. These results link the present work with earlier observations of Greville and Lehmann (1944), who, however, used larger amounts of both ions and tested the whole plasma clotting time.

\section{REFERENCES}

Anstall, H. B., Huntsman, R. G., Lehmann, H., Hayward, G. W., and Weitzman, D. (1959). Lancet, 1, 814

Bettex-Galland, M., and Lüscher, E. F. (1959). Nature (Lond.), 184, 276.

Born, G. V. R. (1956). J., Physiol (Lond.), 133, 61P.

Brown, D. F., McGandy, R. B., Gillie, E., and Doyle, J. T. (1958). Lancet, 2, 933 .

Greville, G. D., and Lehmann, H. (1943). Nature (Lond.), 152, 81. (1944). J. Physiol. (Lond.), 103, 175.

Lehmann, H., and Pollak, L. (1942). Biochem. J., 36, 672.

Macfarlane, R. G., and Biggs, R. (1953). J. clin. Path., 6, 3.

Malkiel-Shapiro, B., Bersohn, I., and Terner, P. E. (1956). Med. Proc., 2, 455.

Schnitzler, B. (1957). Münch. med. Wschr., 99, 81. 